University of Michigan Law School University of Michigan Law School Scholarship Repository

1982

\title{
Individual and Community: An Appreciation of Mr. Justice Powell
}

Christina B. Whitman

University of Michigan Law School, cwhitman@umich.edu

Available at: https://repository.law.umich.edu/articles/330

Follow this and additional works at: https://repository.law.umich.edu/articles

Part of the Judges Commons, Legal Biography Commons, State and Local Government Law Commons, and the Supreme Court of the United States Commons

\section{Recommended Citation}

Whitman, Christina B. "Individual and Community: An Appreciation of Mr. Justice Powell." Va. L. Rev. 68 (1982): 303-32.

This Article is brought to you for free and open access by the Faculty Scholarship at University of Michigan Law School Scholarship Repository. It has been accepted for inclusion in Articles by an authorized administrator of University of Michigan Law School Scholarship Repository. For more information, please contact mlaw.repository@umich.edu. 


\title{
INDIVIDUAL AND COMMUNITY: AN APPRECIATION OF MR. JUSTICE POWELL
}

\author{
Christina B. Whitman*
}

$\mathrm{W}$

HEN the nomination of Lewis F. Powell, Jr., to the Supreme Court of the United States was submitted to the Senate Judiciary Committee ten years ago, much was made of his extraordinary record of service to his city, his state, and his profession. ${ }^{1}$ Justice Powell's career has been a model of individual responsibility to society. His belief in the value of civic life, and in the desirability of making such a life available to everyone, has been a dominant influence in his work on the Supreme Court. In what follows, I shall attempt to define some of the assumptions with which Powell appears to approach the problems-largely constitutional-that have come before him as a Justice. A theme can be discerned: Powell's jurisprudence emphasizes the individual, but not the individual in isolation. Rather, it emphasizes the communal aspects of individual life, the expression of human variety through community. Justice Powell does not define the individual only, or even primarily, in terms of rights against other people or against government. Rather, he is concerned at least as much with the public life of a person, with responsibilities to institutions, to family, and to neighbors. These themes emerge most clearly in Justice Powell's views of federal-state relations, where he takes pains to preserve the more accessible forms of government, and in his conception of

\footnotetext{
* Associate Professor of Law, University of Michigan. I would hike to thank Susan Block, of the University of Michigan class of 1982, for her care and criticism and friendship through the preparation of this article.

The author clerked for Justice Powell during 1975-76. The views attributed to the Justice in this article are derived entirely from a reading of his opinions, but this reading was necessarily informed by the experience of working for one year in the discipline and warmth of that uniquely collegial chambers. Justice Powell's fairness, his honesty, and his inexhaustible concern for people are apparent to all who have had the opportunity to meet him, although his clerks and his family may be the primary beneficiaries of these qualities. We who have worked with him may be best aware of other characteristics: his willingness to listen to argument as long as argument is made, his unceasing desire to learn, and his tolerance of frailty. He is a splendid man.

'See, e.g., Nominations of William H. Rehnquist and Lewis F. Powell, Jr.: Hearings Before the Senate Comm. on the Judiciary, 92d Cong., 1st Sess. 88-90, 115, 123, 129, 132-33, 135 (1971) (statements of Hon. William B. Spong, Jr., A.E. Dick Howard, J. Edward Lumbard, Bernard G. Segal, Hicks Epton, and Phil C. Neal).
} 
the proper role of a judge. A judge, he beheves, has a proper place only as a protector of individual rights, not as an expounder of broad principles or a general overseer of the quality of official conduct. And those rights with which judges properly are concerned should be defined with particularity and with sensitivity to opposing interests, including the interests of other individuals. The variety of human social organizations and the importance of these organizations to a rich and complete human life mean that judges must step cautiously even within their sphere of authority. Caution is important not only because these organizations are worth preserving, but also because judges are hmited in their ability to understand and affect particular institutions through rules of general application.

Justice Powell introduced his concern for community autonomy and its importance to the individual in one of the first opinions he authored as a Supreme Court Justice. ${ }^{2}$ In subsequent opinions, this theme is played out in Justice Powell's concern with federal-state relations and with the proper role of a judge.

\section{The Keyes Opinion: An Introduction to Community Values}

Shortly after he assumed his seat on the Court, Justice Powell wrote a separate opinion that was a remarkably personal introduction to the values and approach of the new Justice. The case was Keyes $v$. School District No. $1 .^{3}$ In that opinion, a majority of the Court accepted a distimction between de facto and de jure discrimination for the purpose of determining when a school board has violated the command of Brown v. Board of Education." Justice Powell's opinion, concurring in part and dissenting in part, took a position that has not been characteristic of his work-he stood virtually alone in arguing for an expansion of constitutional protection. ${ }^{5}$ The opinion is also remarkable in that Justice Powell spoke

\footnotetext{
2 Keyes v. School Dist. No. 1, 413 U.S. 189, 217 (1973) (Powell, J., concurring in part and dissenting in part).

3 413 U.S. 189 (1973).

347 U.S. 483 (1954). See 413 U.S. at 208.

- Justice Powell rejected the de facto/de jure distinction and held instead that a prima facie constitutional violation exists whenever there is evidence that segregated schools exist to a substantial degree within a system. 413 U.S. at 224 (Powell, J., concurring in part and dissenting in part). In Justice Powell's view, his approach is preferable because in the context of school segregation, it is essential to "formulate constitutional principles of national
} 
quite openly as a southerner. He argued that the majority's distinction is unacceptable because it, in effect, treats school segregation as a problem unique to the South. ${ }^{6}$

The Keyes opinion is most important-and more typical of Justice Powell's work-for the insight that it gives into the role that community values play in Powell's thinking. It also illustrates the qualities that would best characterize his subsequent work on the Court-restraint and a reluctance to adopt all-inclusive solutions. These characteristics are related. As I shall indicate, it is the need to promote variety and strength in local communities that leads Justice Powell to caution in proposing judicial solutions.

The centrality of community values and the concern for judicial caution are most clearly illustrated in those parts of the Keyes opinion where Justice Powell discussed busing as a remedy for the effects of segregation. Powell began by arguing that "equitable remedies must be approached" with an "even-handed spirit," avoiding "[o]verzealousness in pursuit of any single goal." $\mathrm{He}$ then elaborated at some length upon the elements that a district judge should consider in drafting a desegregation decree. These are not limited to constitutional, or even strictly legal matters. Instead, Justice Powell tried to articulate what might most trouble ordimary citizens who would be affected by the decrees. The opinion emphasizes the disruptive effects of busing-perhaps because Powell could not avoid viewing the problem from the perspective of a school board meinber and a parent, perhaps because he felt that the interests in favor of desegregation are too obvious to require restatement at length. But the tone and the approach indicate an effort to grapple with both sides of the problem.

Justice Powell attempted to be as honest as possible about the

rather than merely regional apphication." Id. at 219. In other opinions where the cost to constitutional values is not, in his view, so high, it is precisely the national nature of constitutional principles that leads him to argue that the Constitution should be read narrowly. See, e.g., Gregg v. Georgia, 428 U.S. 153, 176 (1976) (opinion of Stewart, Powell \& Stevens, JJ.); Furman v. Georgia, 408 U.S. 238, 462 (1972) (Powell, J., dissenting).

- Powell disapproved of the de facto/de jure distinction because it would mean that school boards in the Soutb, but not those in the North, would be required to respond to a problem they both share. Segregated schools in urban areas everywhere, he insisted, are due fundamentally to segregated residential and migratory patterns rather than to stateimposed segregation: "This is a national, not a southern, phenomenon." 413 U.S. at 223 (Powell, J., concurring in part and dissenting in part).

Id. at 240. 
considerations that influence his view. He directly addressed the desire of parents to retain a voice in the school their children attend, the need for community, the fear that long hours of busing will affect the quality of life of young children, and the financial drain on public schools. Characteristically, Justice Powell's conclusion was not a deflnite rule for general application. Instead, primary responsibility for decision in speciflc cases is entrusted to the lower courts. ${ }^{8}$ Justice Powell's purpose in articulating the competing interests was to give the lower courts guidance, not to preempt their conclusions. This deference to lower courts is essential because Justice Powell sees the judiciary as an institution best equipped to resolve particular disputes-and it does this most successfully by focusing on the details of each case, on the interests that are really at stake for the individuals and the community actually involved. ${ }^{\circ}$

Powell's desire to encourage individuals to express their interests through community institutions is apparent in his recognition and articulation of the interests described above. It is also apparent in his emphasis on the importance of those nonconstitutional tasks that are typically the concern of state and local government. ${ }^{10}$ "[T]he foremost goal of any school system," he wrote, is not desegregation, but "the best quality education for all pupils." gation, he reminded the Court, is but a means to that end. Powell also recognized the practical constraints faced by those who run local institutions-their need for flexibility, for funds, and for community and parental support. ${ }^{12}$ Finally, Powell took pains to stress the individual's ties to his local governing institutions. In elaborating on the importance of support for public education, he offered a remarkable description of local government as an arena for personal involvement:

Community support, interest, and dedication to public schools may well run higher witl a neighborhood attendance pattern: distance may encourage disinterest. Many citizens sense today a decline im the intimacy of our institutions-home, clurch, and school-

8 Id. at 241.

Id. at 251.

10 Id. at 240.

11 Id. at 242.

12 Id. at 245-51. 
which has caused a concomitant decline in the unity and communal spirit of our people. I pass no judgment on this viewpoint, but I do believe that this Court should be wary of compelling in the name of constitutional law what may seem to many a dissolution in the traditional, more personal fabric of their public schools. ${ }^{13}$

The key to understanding much of Justice Powell's work-despite his faint disclaimer in the quote above-lies in his desire to encourage and preserve this strong personal tie between each individual and the institutions that directly affect his life. Powell simply is not ready to give up on this ideal and joim those who stress the mass nature of twentieth-century society. It is an ideal that he finds at the core of the structures created by the Constitution. In questions of federalism this means, among other things, that the lower levels of government, those most accessible to influence by individuals, should be sufficiently strong, in terms of manpower, funds, and scope of authority, to allow the citizen who chooses to play a political role some real measure of control over those issues that are likely to matter most to him. In questions of the exercise of judicial authority, the ideal means that a judge should avoid broad solutions that respond to group problems but ignore other consequences to individual and community life.

It is his perspective on the importance of an individual's involvement in the community that enables Justice Powell to combine an individual-oriented jurisprudence with a commitment to judicial restraint. Unlike many contemporary jurists, Powell does not define personal fulfillment wholly, or even primarily, in terms of the exercise of rights standing in opposition to the claims of society. On the contrary, Powell appears to view a person as most fully hnman im his civic life, in fulfilling obligations rather than asserting rights. Indeed, Powell stresses, an imdividual's interests typically grow out of such obligations as, for example, im Keyes, a parent's concern for the education of his child. The established social structure of a community, even a region of the country, may provide a context in which people define themselves as firmly through communal bonds as through any independent sense of self.

This understanding of the individual in terms of his obligations lies at the core of Justice Powell's judicial conservatism. It is essen-

13 Id. at 246 (emphasis added). 
tial that, while protecting rights, a judge also take pains to preserve those bonds that connect people. ${ }^{14}$ In the name of vindicating human rights, the national government, and particularly its judges, should not destroy those things that matter most to many people. Justice Powell's concern not to disturb unnecessarily the functioning of institutions is most obvious in those opinions, like Keyes, that involve education. For example, in Ingraham $v$. Wright, ${ }^{15}$ Justice Powell, writing for the Court, rejected a constitutional challenge to corporal punisliment in public schools. Because public schools are "open" institutions, Powell wrote, they can be supervised by the community. Therefore, students, unhike, for example, prisoners, ${ }^{16}$ have "little need for the protection of the Eiglith Amendment," and the safeguards that the common law provides are sufficient to meet the requirements of procedural due process. ${ }^{18}$ Similarly, in his dissent in Goss $v$. Lopez, ${ }^{18}$ Powell ex-

14 That Justice Powell's respect for community autonomy stems from the community's role in preserving traditional honds is evidenced by his willingness to strike down local determinations that sever those bonds. In Moore v. City of East Cleveland, 431 U.S. 494 (1977) (plurality opinion), Powell, writing on behalf of a plurality of the Court, struck down a local zoning ordinance that prohibited a grandmother from living with her son and two grandsons; he concluded that such an ordinance runs afoul of the substantive due process standards of tbe fourteenth amendment. Justice Powell stated quite clearly his view that the Constitution was designed to protect and preserve particular social traditions:

Appropriate himits on substantive due process come not from drawing arbitrary lines but rather from careful "respect for the teachings of history [and] solid recognition of the basic values tbat underlie our society." . . . Our decisions establish that the Constitution protects the sanctity of the family precisely because tbe institution of the family is deeply rooted in tbis Nation's history and tradition. It is througb the family that we inculcate and pass down many of our most cherished values, moral and cultural.

Id. at 503-04 (quoting Griswold v. Connecticut, 381 U.S. 479, 501 (1965) (Harlan, J., concurring in the judgment)). Justice Powell went on to say: "Ours is by no means a tradition limited to respect for the bonds uniting the members of the nuclear family. The tradition of uncles, aunts, cousins, and especially grandparents sbaring a household along with parents and children has roots equally venerable and equally deserving of constitutional recognition." Id. at 504. Thus, the Court's obligation under the Constitution is to ensure that government does not intrude upon those who live according to this tradition. Similar protection is not provided to living arrangements of unrelated individuals, for these lack deep roots in American culture. Id. at 498 (distinguishing Village of Belle Terre v. Boraas, 416 U.S. 1 (1974)).

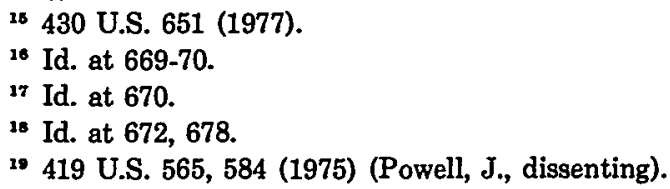


pressed his belief that the majority of the Court erred when it focused on the rights of students against their teacher or the state. Instead, he argued, the state's interests and the pupil's interests are congruent. It is in the student's interest to accept the teacher's authority, to learn respect for the rights of others. In arguing this point, Justice Powell was not afraid to be very personal. He recalled "warm memories of our teachers," contrasting that to the majority's approach, which, Powell said, introduces into the schoolroom that "faceless" "conflict of interests" found in the "competitive and adversary environment of the adult, commercial world."

Justice Powell's respect for institutional autonomy has not been limited to pubhic schools and other local organizations. In Schlesinger $v$. Councilman, ${ }^{22}$ for example, Powell held against judicial interference in military courts-martial. He stressed that the military is "a specialized society separate from civilian society," a society in which a premium is appropriately placed on respect for duty and on a special level of disciphne. ${ }^{23}$ In Cannon $v$. University of Chicago, ${ }^{24}$ Powell dissented from the majority's conclusion that a private cause of action based on alleged sex discrimination in admissions to medical school could be implied under title IX of the Education Act Amendments of 1972.25 Justice Powell refused to read the statute more broadly than was absolutely necessary. He asserted that title IX "trenches on the authority of the academic community to govern itself, an authority the free exercise of which is critical to the vitality of our society."28 In both cases, important national interests arguably supported institutional autonomy-military preparedness in Schlesinger, academic freedom in Cannon-but Justice Powell's concern for this autonomy also reflects his desire to preserve a variety of frameworks in which an individual can find a community that shares his own values and in

\footnotetext{
20 Id. at 594 n.12.

21 Id. at 594-95 n.13.

22420 U.S. 738 (1975).

2s Id. at 757 (quoting Parker v. Levy, 417 U.S. 733, 743 (1974)).

34441 U.S. 677 (1979).

2s Id. at 730 (Powell, J., dissenting). See Education Act Amendments, § 901(a), Pub. L. No. 92-318, 86 Stat. 235 (1972).

36 441 U.S. at 747 (citing, inter alia, Regents of the Univ. of Cal. v. Bakke, 438 U.S. 265, 311 (1978) (opinion of Powell, J.)).
} 
which he can play a significant role.

That judges should be reluctant to disturb community bonds in the name of vindicating constitutional rights does not mean, for Justice Powell, that individuals do not remain paramount. Communities should be protected because of their importance to the individuals who create them, but neither courts nor communities may sacrifice even one person for the collective good. This determination that the individual is of ultimate importance is most evident in Justice Powell's persistent refusal to remedy wrongs by imposing burdens upon innocent people. An early version of this principle appears in Keyes, where Powell argued that wide-scale busing is troublesome because it does not burden the local school officials who committed constitutional wrongs, but rather "children and parents who did not participate in any constitutional violation."

In Franks v. Bowman Transportation $\mathrm{Co} .{ }^{28}$ that principle led Powell to dissent from the majority's decision to approve a form of class relief (retroactive seniority) at the expense of those who are "not the wrongdoers who have no claim to the Chancellor's conscience, but rather are innocent third parties."28 Powell was cold to the argument that the seniority expectations of white workers are illegitimate because they are based on past discrimination in hiring by the employer.

- Acceptance of the job when offered hardly makes one an accessory to a discriminatory failure to hire someone else . . . . [T]he incumbent's expectancy does not result from discrimination against others, but is based on his own efforts and satisfactory performance. ${ }^{30}$

Despite his general deference to more representative branches, Powell also is willing to challenge legislative decisions that ignore individual claims in furtherance of social progress. In his opinion in Regents of the University of California v. Bakke, ${ }^{31}$ Powell reiterated that "there is a measure of inequity in forcing innocent persons . . . to bear the burdens of redressing grievances not of their

\footnotetext{
${ }^{27} 413$ U.S. at 250 (Powell, J., concurring in part and dissenting in part).

28424 U.S. 747 (1976).

${ }^{28}$ Id. at 789 (Powell, J., concurring in part and dissenting in part).

${ }^{30}$ Id. at $788-89$ n.7.

${ }^{31} 438$ U.S. 265 (1978).
} 
making." 32 He emphasized that absent a violation of the Constitution or a statute, "it cannot be said that the government has any greater interest in helping one individual than in refraining from harming another."ss Although he ultimately approved affirmative action to attain a diverse student body, Justice Powell rejected the California program because it insulated minorities from competition with other applicants. It is possible to achieve diversity, he argued, without violating an applicant's constitutional "right to individualized consideration without regard to his race." This is a right Powell derived from sources that run even deeper than the Constitution: "Fairness in individual competition for opportunities . . . is a widely cherished American ethic. Indeed, in a broader sense, an underlying assnmption of the rule of law is the worthiness of a system of justice based on fairness to the individual."ss

\section{Community and the Democratic Process}

Justice Powell has been a consistent advocate of minimizing federal interference in state and local government. ${ }^{36}$ Yet, it bears repeating, the preservation of local and regional communities is not, for him, an end in itself. Rather, it is important in large part because, in contrast to the national government, those communities still provide an arena for the exercise of individual influence. Individual influence is important both because civic involvement is essential to personal growth and because individual interests are best protected by a government in which the voice of each citizen can be heard.

Lower-level government will continue to play this role only if it continues to attract intelligent and caring people and remains open to all citizens, not just to lawyers. A primary reason for Justice Powell's opposition to the expansion of hability for state and local offices has been his fear that government service will become safe only for those who are experts in the law. ${ }^{37}$ In Wood v. Strick-

\footnotetext{
32 Id. at 298 (opinion of Powell, J.).

33 Id. at 308-09.

24 Id. at 318 n.52 (emphasis added).

23 Id. at 319 n.53.

s6 For a very recent statement of this view, see Justice Powell's concurrence in Parratt v. Taylor, 101 S. Ct. 1908, 1918 (1981) (Powell, J., concurring in the result).

${ }^{37}$ Justice Powell brings a personal fervor to the concern that lower-level government remain attractive, that it provide status and power to those who serve. Even prior to his ap-
} 
land, ${ }^{38}$ he dissented from the majority's conclusion that local school officials are entitled to only a qualified immunity from damage liability. The majority held that immunity could be lost if the official "knew or reasonably should have known that the action he took within his sphere of official responsibility would violate the constitutional rights of the student affected,"39 a standard that Justice Powell characterized as "appear[ing] to rest on an unwarranted assumption as to what lay school officials know or can know about the law and constitutional rights." minded the Court, are drawn-and, he implied, should be drawn-from citizens who have "no unique competency in divining the law."41

Powell's concern goes beyond his fear that the threat of federal litigation will make public service too treacherous for the nonlawyer. $\mathrm{He}$ is also afraid that local government jobs will become so fraught with such threats and, because of "pervasive judicial oversight," so devoid of real authority that even lawyers will be unwilling to serve. In Maine v. Thiboutot, ${ }^{42}$ for example, Justice Powell disagreed emphatically with the majority's interpretation that section $1983^{43}$ allowed private actions against state and local officials for violations of federal statutes. ${ }^{4}$ He described this interpretation as a "new intrusion into state sovereignty"

pointment to the Supreme Court, Justice Powell was able to combine his technical expertise as a lawyer with considerable pohtical influence as an individual. Justice Powell has served as Chairman of the Richmond Public School Board (1952-61), as President of the Virginia Board of Education, as a member of the state Constitutional Revision Committee, as a member of the National Colnmission on Law Enforcement and Administration of Justice (1965), and as a member of President Nixon's Blue Ribbon Defense Panel (1969). His participation in professional societies was even more extensive. He has served as President of the American Bar Association (1964-65), as President of the American College of Trial Lawyers (1969-70), and as President of the American Bar Foundation (1969-71). Lawyers are in a unique position to exercise influence of this sort, as Justice Powell would be eager to acknowledge, but a recurring theme in his writing on the Court has been the need to make public service a practical and attractive option for nonlawyers.

${ }^{38} 420$ U.S. 308 (1975).

s9 Id. at 322. Immunity can also be lost if the official "took the action with the malicious intention to cause a deprivation of constitutional rights or other injury to the student." Id.

10 Id. at 329 (Powell, J., concurring in part and dissenting in part).

11 Id. at 331.

42448 U.S. 1 (1980).

4s 42 U.S.C. § 1983 (1974).

14448 U.S. at 11 (Powell, J., concurring in part and dissenting in part).

18 Id. at 33. 
that the resulting harrassment of local officials ${ }^{48}$ would so denigrate their jobs as to leave no room for meaningful participation.

In his concurrence in Schneckloth v. Bustamonte, ${ }^{47}$ Justice Powell, for similar reasons, counseled against the expansive use of federal habeas power to reverse state convictions. He described a federal system with strong and independent states as essential to the diffusion of government power. ${ }^{48}$ To ensure state strength, he sought to preserve the dignity and the status of those individuals who sit on state courts. Overuse of habeas review is harmful because it is humiliating: there is "nothing more subversive of a judge's sense of responsibility, of the inner subjective conscientiousness which is so essential a part of the difficult and subtle art of judging well, than an indiscriminate acceptance of the notion that all the shots will always be called by someone else." 49

Justice Powell's desire to himit federal judicial review is particularly strong when the action under challenge is not only local, but also political. In those cases, concern for the strength of states and the principle of separation of power, both fundamental to Powell's jurisprudence, ${ }^{\text {so }}$ combine to counsel restraint.

Justice Powell's concern for preserving local political processes is evident in his opinion for the Court in Warth v. Seldin. ${ }^{51}$ In denying standing to minority individuals who liad sought to challenge an exclusionary local zoning practice, Powell noted that

zoning laws and their provisions, long considered essential to effec-

\footnotetext{
(8) Id. at 23.

67412 U.S. 218, 250 (1973) (Powell, J., concurring).

48 Id. at 263-64 n.20 (quoting Harlan, Thoughts At A Dedication: Keeping the Judicial Function in Balance, 49 A.B.A. J. 943, 943-44 (1963)).

49 Id. at 264-65 (quoting Bator, Finality in Criminal Law and Federal Habeas Corpus for State Prisoners, 76 Harv. L. Rev. 441, 451 (1963)).

so For opinions on the separation of power, see, e.g., Davis v. Passman, 442 U.S. 228, 251 (1979) (Powell, J., dissenting); Simon v. Eastern Ky. Welfare Rights Org., 426 U.S. 26 (1976); United States v. Richardson, 418 U.S. 166, 188-91 (1974) (Powell, J., concurring). Whenever possible, Powell believes, hard choices should be made through the political process, because of its greater sensitivity to the needs and values of citizens. Even when Congress would prefer to leave decisionmaking to the courts, "[i]t does not follow . . . that this Court is obliged to indulge Congress in its refusal to confront these hard questions." Cannon v. University of Chicago, 441 U.S. at 743 n.14 (Powell, J., dissenting). Because an individual's influence is probably greater at the state and local level, and because differences best may be expressed and accommodated there, the value of having disputes resolved in a local political forum is even greater than when the powers to be separated are both national.

81422 U.S. 490 (1975).
} 
tive urban planning, are peculiarly witlin the province of state and local legislative authorities. They are, of course, subject to judicial review in a proper case. But citizens dissatisfied with provisions of such laws should not overlook the availability of the normal democratic processes. ${ }^{52}$

Perhaps the most dramatic illustration of Justice Powell's insistence that important questions be resolved through local politics is the opinion in Gregg v. Georgia, ${ }^{53}$ coauthored by Justices Stewart, Powell, and Stevens. In a section that draws heavily on Powell's earher dissent in Furman v. Georgia, ${ }^{54}$ Gregg rejects the argument that capital punishment is, under all conditions, a violation of the eighth amendment's ban on cruel and unusual punishment. In Furman, the Court had concluded that the death penalty was unconstitutional as applied, but had left open the question whether the eighth amendment absolutely prohibited the sanction. In Gregg, the Court held that on this issue "the constitutional test is intertwined with an assessment of contemporary standards and the legislative judgment weighs heavily in ascertaining such standards." ${ }^{25}$ Consequently, the Court emphasized the fact that a significant number of states had, since Furman, enacted statutes permitting capital punishment; the Court read this to indicate that "a large proportion of American society continues to regard it as an appropriate and necessary criminal sanction." ${ }^{36}$ In considering the further question whether the punishment had a valid penological justification, the three Justices found sufficient justification in the community's need to express its moral outrage. ${ }^{.7}$ And the hotly debated issue whether capital punishment has a deterrent effect was left to state legislators, who could evaluate the statistical evidence "in terms of their own local conditions and with a flexibility of ap-

${ }^{82}$ Id. at 508 n.18. The standing decision was also based on the Court's conclusion that the petitioners had failed to demonstrate that they had suffered personal harm from the challenged practices. Id. at 509. See notes 103.06 infra and accompanying text.

In Ingraham, see notes 15-18 supra and accompanying text, Powell deferred to local political processes when he beld that a state's common-law remedies provided adequate due process protection against a local institution-here a public school-that was "open" to public surveillance. 430 U.S: at 670 .

ss 428 U.S. 153 (1976) (opinion of Stewart, Powell \& Stevens, JJ.).

st 408 U.S. 238, 414 (1972) (Powell, J., dissenting).

${ }^{\text {ss }} 428$ U.S. at 175 (opinion of Stewart, Powell \& Stevens, JJ.).

${ }^{\text {so }}$ Id. at 179.

s7 Id. at 183-84. 
proach that is not available to the courts."88 In sum, the opinion rejected a flat constitutional prohibition because the Justices preferred to defer to "the ability of a legislature to evaluate, in terms of its particular State, the moral consensus concerning the death penalty and its social utility as a sanction." When the constitutional issue is so closely tied to moral questions, the Justices thought it especially important that "the people [be permitted] to express their preference througl the normal democratic processes."60

\section{The Judicial Role}

\section{A. Limits of Knowledge and Competence}

Closely related to Justice Powell's concern for community autonomy are his views about a judge's proper role. He beheves that judges, whether state or federal, appellate or trial, should proceed with great caution when the cases before them raise the potential of disruptimg communities or institutions.

At one level, Powell's judicial caution simply reflects a widely held view of the place of an independent judiciary in a democratic society: judges are best equipped to protect individuals who assert quite specific claims to relief, but should defer to more democratically based branches of the government when otlier sorts of disputes are involved. In otler words, the judiciary can and must protect minorities against specific abuses of government power, but it is incompetent to police official conduct generally through broad rules designed to vindicate the interests of groups or classes of individuals. These are arguments that Powell frequently makes, ${ }^{81}$ and they are related to the argument, elaborated above, that lower levels of government sliould be preserved as arenas of individual influence.

There is yet another argument for judicial restraint that may be, to Powell, even more compelling than claims derived from democratic theory: if it is true that community bonds provide an essential avenue for individual fulfillment, it is important that judges

${ }^{88}$ Id. at 186.

so Id. at 186-87.

so Id. at 176.

1 See, e.g., Warth v. Seldin, 422 U.S. at 500; United States v. Richardson, 418 U.S. 166, 188, 192 (1974) (Powell, J., concurring). 
not compel all communities to fit the same mold. Justice should be specific to avoid unnecessary disruption. Destruction of social order, of the various contexts in which each person makes his own life is, Justice Powell appears to beheve, itself a significant threat to human freedom. The social order should not be endangered by ill-considered efforts to restructure power with expansive judicial rules drafted to redress what often may be merely a temporary or minor abuse of government power.

There is an epistemological aspect to this argument. Because communities are composed of individuals, and individuals vary, communities can be understood only by focusing on specific circumstances. Powell is suspicious of advocates and judges who propose simple and far-reaching solutions. A solution that responds to abstract matters of principle and policy and ignores the specific may destroy communities and traditions that have been imperfectly understood. It may choose too quickly to sacrifice fairness to individuals for loyalty to principle, and judicial solutions are not undone easily when the reasoning behind them proves flawed. Often a judge will never know whether his solution has worked, and he will seldom be able to count its costs. Caution, therefore, is justified by the hinits of judicial competence and by the special susceptibility of judges to overlook the limits of human knowledge about complex organizations.

Powell's distrust of abstract questions and all-inclusive answers has been apparent from his first days on the Court. ${ }^{62}$ One of his most explicit statements of such distrust can be found in his dissent in Furman v. Georgia, ${ }^{\text {ss }}$ where he first rejected a conclusive condemnation of capital punishinent. Petitioners in Furman argued that the death penalty-in all its forms and however administered-violates the constitutional ban on cruel and unusual punishment. ${ }^{\text {ot }}$ This argument, Powell wrote, "goes far beyond the traditional process of case-by-case inclusion and exclusion."

${ }^{62}$ See, e.g., Keyes v. School Dist. No. 1, 413 U.S. at 241-52 (Powell, J., concurring in part and dissenting in part).

os 408 U.S. at 414 (Powell, J., dissenting).

or Although only two Justices called for the abohtion of all capital punishment, Justice Powell found "unpersuasive" the reasoning of the Justices who called for some "less-thanabsolute-abolition." Id. at 415-16. Thus, he determined to focus only upon the broader rules urged by the petitioners. Id. at 416 .

ss Id. at 430. 
tioners sought "a precipitate and final judicial end." ment was not limited to the application of the death penalty in the case before the Court, but assumed "that the ultimate wisdom as to the appropriateness of capital punishment under all circumstances, and for all future generations, has somehow been revealed." "87 Powell would be more receptive to an equal protection argument based on statistical proof by a particular defendant that he had received a sanction more severe than that received by others not of his race for the same crime. ${ }^{88}$ Powell also rejected an across-the-board rule that capital sanctions are inappropriate for the crime of rape: "Although this case-by-case approach may seem painfully slow and inadequate to tlose who wish tlie Court to assume an activist legislative role in reforming criminal punishments, it is the approach dictated both by our prior opinions and by a due recognition of the limitations of judicial power."

As these quotations suggest, the nondemocratic nature of judicial review was one reason for Powell's reluctance to act: "In a democracy the first indicator of the public's attitude must always be found in the legislative judgments of the people's cliosen representatives." The majority's "sweeping" decision tliat the imposition of capital punishment in the cases before the Court violated the Constitution "reflects a basic lack of faitl and confidence in the democratic process." "71 But also critical was the abstract nature of such a broad decision: "The sobering disadvantage of constitutional adjudication of this magnitude is the universality and permanence of the judgment. The enduring merit of legislative action is its responsiveness to the democratic process, and to revision and change ...."."?

Abstractions limit judicial understanding even when judges deal in remedies rather than in abstract prohibitions. Before ruling, Powell believes, a judge should be as fully aware as possible of the actual practical constraints on the people in the particular institutions that will be required to respond to his orders. Otlierwise, he

\footnotetext{
so Id.

67 Id. at 431.

so Id. at 449 .

s9 Id. at 461 .

70 Id. at $436-37$.

71 Id. at $464-65$.

12 Id. at 462.
} 
cannot predict the consequences of his actions. In his own opinions, Justice Powell has repeatedly tried to identify the kinds of institutional pressures that may exist. In doing this, he has not claimed that the constraints that he articulates exist in all organizations. Instead, he has tried to describe the kinds of factors that should counsel restraint or that trial judges should elucidate in the course of hitigation. He fears that judges will be tempted to conceal their lack of knowledge by ignoring and downplaying potential costs.

This may be most likely to happen when those costs are financial. In Keyes, as we have seen, Justice Powell was concerned that a constitutional busing requirement would place serious econoinic burdens on school districts already short of funds. ${ }^{73}$ In Cannon $v$. University of Chicago, where Powell dissented from the majority's conclusion that a private cause of action can be imphed under title IX, he again counseled agaimst imposing financial burdens on educational institutions. ${ }^{74}$ Despite the weaknesses of the rejected apphicant's case, he argued, "these schools have been forced to use their scarce resources to defend against this suit,"7s and "[t]he burden of expensive, vexatious litigation upon institutions whose resources often are severely limited may well compel" institutions to develop more objective admissions criteria, criteria that are less educationally useful but more easily defended in the courtrooln. ${ }^{78}$ Similarly, in Mathews $v$. Eldridge, ${ }^{77}$ Justice Powell warned that requiring additional procedural safeguards before the suspension of Social Security benefits would entail costs in terms of money and administrative time, costs that "may in the end come out of the pockets of the deserving since resources available for any particular program of social welfare are not unlimited."78

In addition to financial consequences, Justice Powell has addressed the less tangible effects that court decisions may have on institutional hife. In Cannon, he was troubled that the response of the Court to the "abstract". merits of a (probably unwinnable)

\footnotetext{
73413 U.S. at 248 (Powell, J., concurring in part and dissenting in part). See notes 7-9 supra and accompanying text.

7441 U.S. at 730 (Powell, J., dissenting).

${ }^{73}$ Id. at 748 n.19.

76 Id. at 747 (footnote oinitted).

77424 U.S. 319 (1976).

${ }^{36}$ Id. at 348.
} 
claim of gender discrimination would push educational institutions to adopt a less personal approach to their own participants. ${ }^{78}$ In Keyes, he warned that judicial oversight of routine administrative decisions may cripple the functioning of institutions and deaden the spirits of officials. ${ }^{80}$ In Ingraham $v$. Wright, ${ }^{81}$ he mentioned the importance of preserving "the teacher's ability to maintain discipline in the classroom"82 and counted the fact that teachers may not themselves be free to decide whether to use corporal punishment to that end as a cost to be weighed in evaluating the requirements of procedural due process. ${ }^{83} \mathrm{He}$ also pointed out, in an insight that cuts across the normal assumptions of pubhic interest litigation, that the formalization of school disciplinary proceedings actually may harn children subject to sanctions by increasing their anxiety. ${ }^{84}$

Finally, Justice Powell has been attentive to the personal costs to other members of a community that may result from judicial efforts to remedy injuries to complainants. For exainple, in Wood $v$. Strickland, he dissented from the majority's conclusion that state and local officials can be held hable when they violate settled constitutional rights. ${ }^{80}$ This is asking too inuch of nonlawyers, Powell argued. And he persistently challenges judicial remedies for discrimination that impose burdens not only on the wrongdoers, but also on "innocent third parties."

\section{B. The Ends of Litigation}

Justice Powell's efforts to limit the role of the federal judiciary follow naturally from his awareness of the dangers of over-ainbitious judicial rulemaking. Not only does a federal judicial decision inevitably intrude on the authority of the states, but federal judges, being farther removed from the practical consequences of their decisions, are more likely than state judges to adopt abstract

79 See note 76 supra and accompanying text.

so 413 U.S. at 232-35 (Powell, J., concurring in part and dissenting in part).

81 430 U.S. 651 (1977). See notes 15-17 supra and accompanying text.

82430 U.S. at 681 n.50.

s3 Id. at $680-81$.

s4 Id. at 681 n.51.

ss See notes 38-41 supra and accompanying text.

${ }^{86}$ See Franks v. Bowman Transp. Co., 424 U.S. at 789 (Powell, J., concurring in part and dissenting in part). See also notes $28-30$ supra and accompanying text. 
solutions to broad problems without sufficient regard for consequences.

A central principle upon which Justice Powell relies in restricting the federal judicial role is that the primary responsibility of any judge-state or federal-is to respond to personal claims of injury or specific requests for rehef, rather than to serve as a general supervisor of official conduct. This theme is most evident in two areas about which Justice Powell has demonstrated the most enduring concern-habeas corpus and justiciability. In both of these areas, Justice Powell's focus on personal claims of injury has led him to restrict the kinds of claims that will be heard by a federal court.

In a series of opinions, Powell has elaborated upon the view that federal habeas should be reserved for rehef to the innocent individual who has been erroneously incarcerated. He argued in his concurrence in Schneckloth $v$. Bustamonte that federal habeas has been extended inappropriately beyond its historic bounds "not to further justice on behalf of arguably innocent persons but all too often to serve mechanistic rules quite unrelated to justice in a particular case." ${ }^{\text {8z }}$ In Stone v. Powell, ${ }^{88}$ Justice Powell, for the Court, held that a state prisoner who had an opportunity to hitigate a fourth amendment exclusionary rule claim in state court could not raise it in federal habeas. He pointed out that even when the exclusionary rule is used during the trial of the accused in state court it has significant costs, ${ }^{89}$ for it diverts attention "from the ultimate question of guilt or innocence that should be the central concern in a crimimal proceeding."90 These costs may be justified at trial and on direct appeal, ${ }^{91}$ but they are intolerable when combined with the costs of federal collateral review. ${ }^{92}$ In the federal forum, at least, the issue should be "the basic justice of . . . incarceration." "9s

Concurring in the judgment in Rose v. Mitchell," Powell con-

87 412 U.S. at 259 (Powell, J., concurring).

ss 428 U.S. 465 (1976).

so Id. at $489 \&$ n.27.

${ }^{\circ}$ Id. at 490 .

or Id. at 492 . Powell is not convinced that even at the trial level, the exclusionary rule is worth its costs, see id. at $492 \& \mathrm{n} .32$, but for purposes of this case, he assumed that it is, see id. at 492-93.

${ }^{82}$ See id. at $491 \&$ n.31.

os See id.

of 443 U.S. 545 (1979). 
tended that claims of discrimination in the selection of a grand jury also should not be heard in federal habeas. ${ }^{95}$ Preventing discrimination is important, but "[h]abeas corpus is not a general writ meant to promote the social good or vindicate all societal interests of even the highest priority." " Rather, it was "developed by the law to serve [the] precise and particular purpose" of protecting an innocent claimant from unjust incarceration. ${ }^{97}$

Justice Powell's insistence that the federal courts not be used to vindicate group grievances comes through even more clearly in his opinions on justiciability. As early as his concurrence in United States $v$. Richardson, ${ }^{88}$ he described the core issue in taxpayer or citizen standing cases as whether "federal courts should entertain public actions"99 and answered in the negative. ${ }^{100}$ His answer was based in part on his behef that courts who exercise power "as indiscriminately as is now being urged"101 risk retaliation by the rep-

os Id. at 579 (Powell, J., concurring in the judgment).

ot Id. at 586 (emphasis in original).

97 Id.

os 418 U.S. 166, 180 (1974) (Powell, J., concurring).

90 Id. at 186.

100 Id. at 196.

101 Id. at 191. Justice Powell's determination to limit the role of the federal courts in policing government conduct explains his hostility to efforts to "make a federal case" out of an issue that could be resolved by other ineans. In Warth, for instance, Powell described one plaintiff group's federal claim as little "'more than an [ingenious academic] exercise in the conceivable." " 422 U.S. at 509 (quoting United States v. SCRAP, 412 U.S. 669, 688 (1973)).

Powell does recognize that the federal courts themselves are primarily responsible for encouraging lawyers to cast their cases in a form that will support federal hitigation. Not only have they heard claims despite the plaintiff's apparent lack of standing, see, e.g., Deposit Guar. Nat'l Bank v. Roper, 445 U.S. 326, 353 n.13 (1980) (Powell, J., dissenting), but they also have found constitutional violations that, in Powell's view, do not reflect actual injuries. Dissenting in Castaneda v. Partida, 430 U.S. 482 (1977), Powell described his "sense of unreality when Justices here in Washington decide solely on the basis of inferences from statistics that the Mexican-Americans who control the levers of power in this remote border cormtry are manipulating them to discriminate 'against themselves.' " Id. at 518 (Powell, J., dissenting).

Against this background, Powell's hostility to doctrinal developments that encourage artful pleadings or inflated claims may be better understood. This appears to be one reason for his refusal in Carey v. Piphus, 435 U.S. 247 (1978), to bold that a violation of procedural due process automatically entitles a plaintiff to recover substantial damages under 42 U.S.C. $\S 1983$ (1976). More explicitly, in Rose v. Mitchell, he argued against expansive interpretations of the scope of federal habeas on the ground that it encourages lawyers to raise "[f]ederal constitutional challenges . . . in almost every state criminal case." 443 U.S. at 581 (Powell, J., concurring in the judgment). See also Maine v. Thiboutot, 448 U.S. at 11-12, 22, 33 (Powell, J., dissenting); Chapman v. Houston Welfare Rights Org., 441 U.S. 600, 645 
resentative branches and in part on his view that federal courts will be most effective if their limited resources are not diverted from "their historic role" of protecting individuals and minority groups against oppression and discrimination to "some amorphous general supervision of the operations of government."102

Justice Powell pressed this view on belialf of a majority of the Court in the remarkably harsh opinion of Warth $v$. Seldin, ${ }^{103}$ where standing was denied to a wide range of litigants who liad hoped to challenge a town's zoning practices. There Powell articulated what has become his standard approach to standing cases: the Constitution imposes an absolute minimum requirement that a personal stake in the outcome of hitigation be shown by the plaintiff before the case can be called justiciable. ${ }^{104}$ And judicial prudence imposes additional requirements to bar assertion of "public" claims even by those who can establish an individual stake. Because of these "prudential" limitations, no generalized grievance will be heard, and claims of third parties cannot be asserted. ${ }^{108}$ "Without such limitations," Justice Powell noted, "the courts

(1979) (Powell, J., concurring); Hagans v. Lavine, 415 U.S. 528, 551 (1974) (Powell, J., dissenting) (the majority's approach to pendent jurisdiction "would broaden federal question jurisdiction to encompass matters of state law whenever an imaginative litigant can think up a federal claim, no matter how insubstantial, that is related to the transaction giving rise to the state claim").

102418 U.S. at 192 (Powell, J., concurring).

${ }^{10 s} 422$ U.S. 490 (1975). Discussed at notes 51-52 supra and accompanying text.

106 The individual petitioners in Warth were denied standing as persons of low or moderate income because they failed to demonstrate that "absent the respondents' restrictive zoning practices, there is a substantial probability that they would have been able to purchase a lease in Penfield and that, if the court affords the rehef requested, the asserted inability of petitioners will be removed." 422 U.S. at 504. Despite evidence in the record of two housing projects that were denied zoning approval, Justice Powell noted that " $t]$ here is . . . not the slightest suggestion that they would [have been] adequate, and of sufficiently low cost, to meet these petitioners' needs." Id. at 505-06 n.15.

In contrast, in Village of Arlington Heiglits v. Metropolitan Hous. Dev. Corp., 429 U.S. 252 (1977), Justice Powell, writing for the Court, held that a minority plaintiff had standing to allege race discrimination in local zoning because lie could point to a particular housing project, contemplated by another plaintiff, into which le would move if the zoning barrier were removed. Because there was "at least a "substantial probability" that the project would materialize, the plaintiff"s claim was "not dependent on speculation about the possible actions of third parties not before the court." Id. at 264 (quoting Warth v. Seldin, 422 U.S. at 504).

${ }^{103}$ Some petitioners in Warth were denied standing as taxpayers because, even assuming that they could deinonstrate personal harm, prudential concerns barred them from asserting the rights of the third parties excluded from Penfield. 422 U.S. at 509. 
would be called upon to decide abstract questions of wide public significance even though other governmental institutions may be more competent to address the questions and even thougl judicial intervention may be unnecessary to protect individual riglits."108

The following year, in Simon $v$. Eastern Kentucky Welfare Rights Organization, ${ }^{107}$ Justice Powell, again for the Court, refused to find that the constitutionally required "personal stake" existed in a challenge to an Internal Revenue Service ruling that removed certain incentives for treatment of indigents by hospitals. Justice Powell held that in order to demonstrate their personal stake, the indigents must demonstrate not only that tbey "liad been injured in fact" by the ruling, but also that the injury "is likely to be redressed by a favorable decision" by the Court. ${ }^{108}$ Powell was unwilling to speculate on the motivations behind the hospitals' denial of care, and he refused to generalize about hospital bebavior because he felt that the response to any cliange in the ruling would vary from institution to institution. ${ }^{100}$

Powell's insistence that a judge is limited to redressing individual grievances also is decisive in the disposition of cases that are properly before him. He insists that relief be as specific as possible. For example, in Carey $v$. Piphus, ${ }^{110}$ where he rejected the argument tbat compensable injury may be presumed to flow from every denial of due process, Powell stressed that compensation for personal injury is the goal of tort litigation. "Rights, constitutional and otherwise, do not exist in a vacuum. Their purpose is to protect persons from injuries to particular interests, and their contours are shaped by the interests they protect."111 In Estes v. Metropolitan Branches of the Dallas NAACP, ${ }^{112}$ another case involving the appropriateness of busing to achieve racial balance in public schools, Powell dissented from dismissal of the writ of certiorari in an opinion that insisted that the courts cannot achieve and should not attempt to achieve perfectly integrated school sys-

\footnotetext{
108 Id. at 500. See also Singleton v. Wulff, 428 U.S. 106, 131 (1976) (Powell, J., concurring in part and dissenting in part).

107426 U.S. 26 (1976).

108 Id. at 38.

109 Id. at 43.

210435 U.S. 247 (1978).

111 Id. at 254.

11244 U.S. 437 (1980) (per curiam).
} 
tems." Nor should they "embrace all the problems of racial prejudice." "114 Instead, the goal of rehef in a school desegregation case, as in other litigation, is simply to restore the victims of discrimination to the positions they would have been in had there been no violation. ${ }^{115}$

Justice Powell's insistence that judges are to provide redress only for individual injuries that can be traced directly to a violation of the law leads him to conclude that it is inappropriate for judges to attempt to cure the injustices caused by economic inequities or disparities in social status. Judges should not try to effect such cures because they have special competence only in the particular and because they cannot sufficiently control the consequences of their decisions. In refusing to join the majority in Furman, ${ }^{116}$ Powell conceded that capital punishment falls disproportionately on the poor, but that problem, he felt, could not be attributed to the only legal question in the case-a challenge to the severity of the penalties for crime. Rather, the disproportionate burden was due to "social and economic factors that have plagued humanity since the beginning of recorded history, frustrating all efforts to create in any country at any time the perfect society in which there are no 'poor,' no 'minorities' and no 'underprivileged.' "117 These are causes, he went on to say, that "are unrelated to the constitutional issue [of cruel and unusual punishment] before the Court." ${ }^{118}$ Again in Warth, ${ }^{119}$ Justice Powell refused to find standing where "petitioners' descriptions of their individual financial situations and housing needs suggest . . . that their inability to reside in Penfield is the consequence of the economics of the area housing market, rather than of respondents' assertedly illegal acts." 120

Justice Powell is not indifferent to the needs of those who suffer

11s Id. at 438 (Powell, J., dissenting).

114 Id. at 447 (quoting Swann v. Charlotte-Mecklenburg Bd. of Educ., 402 U.S. 1, 23 (1971)).

125 Id. (citing Milliken v. Bradley, 433 U.S. 267, 280 (1977)).

${ }^{118}$ For a discussion of Justice Powell's dissent in Furman, see notes 63-67 supra and accompanying text.

117408 U.S. at 447 (Powell, J., dissenting).

118 Id. at 448.

110 For a discussion of Justice Powell's opinion in Warth, see notes 103-05 supra and accompanying text.

120422 U.S. at 506. 
because of their social and economic status, ${ }^{121}$ but he is convinced that such injuries are "usually beyond judicial correction." a court that engages in social engineering risks affecting communities in ways beyond the judge's awareness and control. This theme has its roots in Keyes, ${ }^{123}$ and Powell also stressed it in his refusal to restructure school financing in San Antonio Independent School District v. Rodriquez: ${ }^{124}$

There is nothing simple or certain about predicting the consequences of massive change in the financing and control of public education. Those who have devoted the inost thoughtful attention to the practical ramifications of these cases have folmd no clear or dependable answers and their scholarship reflects no such unqualified confidence in the desirability of completely uprooting the existing system. ${ }^{125}$

The answer, if there is one, must be discovered through "the legislative processes of the various States."128

A second consequence of Justice Powell's behef that the specific, rather than the abstract, is the proper end of higation is his inclination to balance the costs and benefits of a proposed course of action. This technique, which is often frustrating to those who seek certainty in the law, reflects Powell's view that no principle, even a constitutional one, is so clear and so compelling that it can dictate a rule that will determine results in all situations. When Powell does dictate a result, it tends to be against judicial action; his inchination to balance does not mean that lie lias no consistent perspective. What he liopes to communicate is that judges should take care to understand the consequences of their actions and sliould reserve action when those consequences cannot fully be understood.

Justice Powell's balancing approacl is demonstrated most

121 See, e.g., Memphis Light, Gas \& Water Div. v. Craft, 436 U.S. 1 (1978).

${ }^{122}$ See Estes, 444 U.S. at 451 n.18 (Powell, J., dissentimg). Justice Powell's entire dissent in Columbus Bd. of Educ. v. Penick, 443 U.S. 449, 479 (1979) (Powell, J., dissenting), is a forceful elaboration of this theme. He pointed out, for mstance, that in numerous cities, forced integration of public schools has resulted in a process of resegregation when families have moved or resorted to private education. Id. at 484-85.

123413 U.S. at 250 (Powell, J., concurring in part and dissenting in part).

224 411 U.S. 1 (1973).

128 Id. at 56.

128 Id. at 58. 
clearly by his opinions concerning the exclusionary rule and the scope of procedural due process requirements. ${ }^{127}$ In the exclusionary rule cases, beginning with his concurrence in Schneckloth, Powell has urged the Court to take a "pragmatic" approach: "Our decisions have not encouraged the thought that what may be an appropriate constitutional policy in one context automatically becomes such for all times and all seasons." ${ }^{128}$ Subsequently, in several opinions discouraging the use of the rule, he has weighed the costs of exclusion against the gains to the goals that the rule serves. ${ }^{129}$

Similarly, in the procedural due process cases, such as Mathews $v$. Eldridge ${ }^{130}$ and Arnett $v$. Kennedy, ${ }^{131}$ Powell has weighed the private litigant's interest in avoiding a deprivation and the risk of erroneous government action against the government or public interest in acting in the manner contested, including the interest in minimizing expenses and increasing efficiency. ${ }^{\mathbf{1 3 2}}$ Most frequently, Powell has determined that the government's interests outweigh those of the private litigant, ${ }^{133}$ but he has not been insensitive to the needs of individuals faced with the deprivation of government

${ }^{127}$ It is, however, an approach that Justice Powell finds congenial, and he has used it in a wide range of situations. It appears in opinions that address problems ranging from such quasi-constitutional issues as the prudential limitations on standing, e.g., Singleton v. Wulff, 428 U.S. 106, 122 (1976) (Powell, J., concurring in part and dissenting in part); United States v. Richardson, 418 U.S. 166, 180 (1974) (Powell, J., concurring), and the preemptive effect of the National Labor Relations Act, e.g., Farmer v. United Bhd. of Carpenters \& Joiners Local 25, 430 U.S. 290 (1977), to statutory issues, such as the interpretation of the Clayton Act, e.g., Gulf Oil Corp. v. Copp Paving Co., 419 U.S. 186 (1974). Balancing is particularly common in Justice Powell's opinions concerning remedies for school segregation. See, e.g., Estes v. Metropolitan Branches of the Dallas NAACP, 444 U.S. at 438 (Powell, J., dissenting); Columbus Bd. of Educ. v. Penick, 443 U.S. 449, 479 (1979) (Powell, J., dissenting); Keyes v. School Dist. No. 1, 413 U.S. at 217 (Powell, J., concurring in part and dissenting in part).

128412 U.S. at 270 (Powell, J., concurring).

${ }^{129}$ See, e.g., Stone v. Powell, 428 U.S. 465 (1976) (assertion on federal habeas corpus that state court improperly admitted evidence seized in violation of the fourth amendment); United States v. Calandra, 414 U.S. 338 (1974) (exclusion of questions based on unlawful search and seizure). Cf. Rose v. Mitchell, 443 U.S. at 579 (Powell, J., concurring in the judgment) (assertion on federal habeas corpus of claim of racial discrimination in selection of state grand jury foreman).

130424 U.S. 319 (1976). See notes 77-78 supra and accompanying text.

131416 U.S. 134, 164 (1974) (Powell, J., concurring in part and concurring in the result in part). See also Ingraham v. Wright, 430 U.S. 651 (1977).

${ }^{132}$ See, e.g., 424 U.S. at 335; 416 U.S. at 164.

${ }^{133}$ See cases cited in notes 130-31 supra. 
services "essential to health and safety."184

In its effort to avoid disruptively broad solutions, Justice Powell's jurisprudence leaves much authority to others-to federal trial judges, who are more sensitive to and informed about the needs of the private parties before the court than is the Supreme Court, ${ }^{135}$ and to state officials at all levels of responsibility, whom he would leave relatively free from constitutional restraints.

This deference is dehberate and exphicit. Powell insists that officials other than those who sit on the Supreme Court must be trusted to provide fair treatment to citizens. The Supreme Court, even with the aid of the lower federal courts, simply is not institutionally able to oversee all other government officials. Even if it could perform this task, such supervision would destroy the sense of responsibility that, when it is found in institutions and officials, is the best guarantee of individual rights. Powell repeatedly insists that these other officials are in fact trustworthy and deserve the deference that he is willing to give them.

That state judges can be trusted to sanction violations of the Constitution is a recurrent theme in Justice Powell's work. It is the key to understanding his conclusion in Stone v. Powell that claims based on the fourth amendment's exclusionary rule will not be heard in federal habeas. ${ }^{136}$ Habeas review can be considered a redundant and unnecessary remedy for constitutional claims only if state judges will give those claims serious attention when they are raised initially. In a footnote to the Stone opinion, Justice Powell said:

The policy arguments that respondents marshal in support of the view that federal habeas corpus review is necessary to effectuate the Fourth Amendment stem from a basic mistrust of the state courts as fair and competent forums for the adjudication of federal constitutional rights. The argument is that state courts cannot be trusted to effectuate Fourth Amendment values through fair application of the rule, and the oversight jurisdiction of this Court on certiorari is an inadequate safeguard. . . . Despite differences in institutional environment and the unsympathetic attitude to fed-

\footnotetext{
134 See, e.g., Memphis Light, Gas \& Water Div. v. Craft, 436 U.S. 1, 14 n.15 (1978).

1ss In devising remedies for constitutional wrongs such as school segregation, trial judges can "consider many economic, social, and educational factors . . . factors [that] vary widely from community to community." Estes, 444 U.S. at 444 (Powell, J., dissenting).

${ }^{136}$ See notes 88-93 supra and accompanying text.
} 
eral constitutional claims of some state judges in years past, we are unwilling to assume that there now exists a general lack of appropriate sensitivity to constitutional rights in the trial and appellate courts of the several States. ${ }^{137}$

Earlier, in Schneckloth v. Bustamonte, Justice Powell had argued that "the asserted inadequacy of state procedures and unsympathetic attitude of state judges are far less realistic grounds of concern than in years past."138

Powell places similar trust in nonjudicial officers. He reminded us in Goss v. Lopez that "[w]e liave rehed for generations upon the experience, good faitl and dedication of those who staff our public scliools,"139 and in Mathews $v$. Eldridge, lie insisted that "substantial weiglit must be given to the good-faitl judgments of the individuals charged by Congress witl the administration of social welfare programs that the procedures they liave provided assure fair consideration of the entitlement claims of individuals."140

To fail to trust state officials, Powell fears, is to make tliem untrustwortly, for human beings can be expected to perform well only if given responsibility and respect. ${ }^{141}$ To give up on lowerlevel officials is to give up on the ideal of responsive government, for responsive government requires attention to the particular claims of individual citizens, a task that can be performed only randomly by national officers. We must depend, in most cases, on local officials, who are in a better position, in terms of botl time and knowledge, to assume the responsibility of mastering the de-

137428 U.S. at $493-94$ n.35.

138412 U.S. at 259 n.13 (Powell, J., concurring). See also Schlesinger v. Councilman, 420 U.S. 738 (1975), where Justice Powell noted:

The precise content of constitutional rights almost invariably turns on the context of fact and law in which they arise. State courts are quite as capable as federal courts of determining the facts, and they alone can define and interpret state law. Equally important, under Art. VI of the Constitution, state courts share with federal courts an equivalent responsibility for the enforcement of federal rights, a responsibility one must expect they will fulfill.

Id. at 755-56. Deciding in that opinion against intervention in impending military courtmartial proceedings, Justice Powell also expressed his trust "that the military court system will vindicate servicemen's constitutional rights." Id. at 758.

139419 U.S. at 595 (Powell, J., dissenting). See also Regents of the Univ. of Cal. v. Bakke, 438 U.S. at 318-19 (opinion of Powell, J.); Ingraham v. Wright, 430 U.S. at 681-82; Keyes v. School Dist. No. 1, 413 U.S. at 217 (Powell, J., concurring in part and dissenting in part).

140424 U.S. at 349.

141 See Schneckloth v. Bustamonte, 412 U.S. at 265 (Powell, J., concurring). 
tails of each claim. The Supreme Court's task is to ensure the existence of conditions that nurture this responsibihty.

\section{Some REFLections}

In his tenure on the Supreme Court, Justice Powell has sought to protect and nurture local government and community institutions, and he has urged federal judicial restraint in disturbing traditional bonds. Justice Powell, however, has not always adhered to the principles that he has developed. For example, despite his persistent claims that moral issues must be left to community resolution, he has cooperated with his Brethren in taking from the states control over a woman's decision to bear children and over classifications made on the basis of sex. ${ }^{142} \mathrm{He}$ acknowledges by this that there are situations in which tradition and community become oppressive.

A more troubling departure, at least for me, is Justice Powell's opinion in First National Bank v. Bellotti, ${ }^{143}$ in which he developed a flat constitutional rule that prohibits local communities from imposing himitations on corporate spending designed to infiuence the outcome of public referenda. Powell's more typical insistence that local officials best understand local conditions was forgotten here; his common assertion that judges cannot correct injuries created by disparities in status or wealth, an argument that usually cuts against judicial action, was turned into a justification for his refusal to histen to community fears that corporate resources may be so great as to distort the referendum process. ${ }^{144}$

Other criticisms can be made-more serious because they are not the result of inconsistency, but rather point to problems inherent in the judicial philosophy that I have described. The first of these is relatively minor. An individual-centered jurisprudence requires that decisions be made about who is to count as an individual. Justice Powell can be accused of refusing to accord full respect to the interests of, for example, children, ${ }^{145}$ criminals subject to the

\footnotetext{
${ }^{142}$ See Sandalow, Federalism and Social Change, 43 Law \& Contemp. Probs. 29, 34, 37 (Summer 1980).

14s 435 U.S. 765 (1978).

14 Id. at $789-90$.

14s See, e.g., Bellotti v. Baird, 443 U.S. 622 (1979) (plurality opinion). In Baird, however, Powell at least recognized that a child's privacy right should not be subject to an absolute parental veto. See also Ingralıam v. Wright, 430 U.S. 651; Goss v. Lopez, 419 U.S. at 584
} 
sanction of death, ${ }^{146}$ and fetuses, ${ }^{147}$ although the relevant rulings are consistent with his concern for traditional community values. This is a less telling criticism than it would be were Justice Powell's emphasis on the individual purely rights-oriented. Were that the case, he would be required to articulate exactly how conflicting claims between autonomous and equally worthy creatures could be reconciled. The problem of reconciliation is less troublesome in light of Powell's focus on community, for conflicting claims can be evaluated by reference to roles and relationslips defined by the community rather than by the judge. ${ }^{148}$

A second, and more difficult, problem arises out of Justice Powell's inclination to resolve questions by balancing the factors that he considers relevant. This is a technique that appeals to Justice Powell because it is attentive to variety and avoids the arrogance of less flexible decisions. In practice, lowever, the balancing tecl1nique may encourage judges to play a more intrusive role. Instead of enforcing a deflned and limited set of minimum regulations, the judge is encouraged to become an expert in the practical problems involved in a particular dispute. The temptation is great to take the next step and become a judicial "bureaucrat," devising compromise solutions that respond to a wide range of concerns beyond those properly before the court. Powell's own jurisprudence, to this extent, carries within it the seeds of "public interest" litigation that he elsewhere is at such pains to discourage.

A third problem inherent in Justice Powell's views is that lis willingness to trust other officials and to limit federal judicial supervision of their conduct ignores the basic distrust implicit in the Constitution's diffusion of authority. Perhaps this is unavoidable. The tension deliberately incorporated into the federal structure makes neither trust nor distrust a completely appropriate re-

\footnotetext{
(Powell, J., dissenting).

${ }^{148}$ See, e.g., Gregg v. Georgia, 428 U.S. 153 (opinion of Stewart, Powell \& Stevens, JJ.); Furman v. Georgia, 408 U.S. at 414 (Powell, J., dissenting).

${ }^{147}$ See, e.g., Bellotti v. Baird, 443 U.S. 622 (1979) (plurality opinion).

148 A related problem, and one that may pose more difficulties for Justice Powell, is whether it is appropriate to distinguish among institutions and communities. Justice Powell often draws the line in terms of the historical and traditional roots of the organization. See note 14 supra and accompanying text. He seems to have found it more difficult to understand the claims of certain organizations-for instance, those of labor unions, see, e.g., Connell Const. Co. v. Plumbers \& Steamfitters Local 100, 421 U.S. 616 (1975), or of dissident movements, see, e.g., Lloyd Corp. v. Tanner, 407 U.S. 551 (1972).
} 
sponse. A permanently unstable mixture of the two may be all that is possible, and Justice Powell may believe that an emphasis on trust is an appropriate corrective to the decisions of the Warren Court years. ${ }^{148}$ But his approach may appear callous to litigants who lack his confidence in the good faith of other officials.

Finally, Powell's jurisprudence also may seem callous in that it appears to ignore limitations on the ability of many individuals to play an active public role. In other words, Powell may overestimate the availabihty of alternatives to constitutional litigation in federal courts. ${ }^{150}$ Powell's vision of democracy, which has a markedly Jeffersonian cast, downplays the fact that, because of the accumulation of financial resources and a trend toward centralization tliat goes far beyond tle decisions of the Warren Court, institutions, both private and governmental, may liave a power in society much greater than that of the individuals who play institutional roles. ${ }^{181}$

Justice Powell's response might be that, if this is the case, it creates an inequity that courts cannot redress without risking the indiscriminate destruction of the social context in wlich these powers have flourished. This is a cost tliat he views as too great, for it would leave the individual in a vacuum, perhaps vindicated in asserting his riglits but without a community in which to exercise tliem. Far better, Justice Powell might say, for the courts to preserve existing frameworks and to exercise tlieir autlority by reminding those in power of their obligations.

\section{CoNCLUSION}

Over the last decade, Justice Powell las followed a jurisprudence

148 See text accompanying notes $137-38$ supra.

${ }^{160}$ See, e.g., Rose v. Mitchell, 443 U.S. at 583 (Powell, J., concurring in the judgment). There Powell argues that discrimination in the selection of grand juries may be attacked through federal criminal sanctions and through private actions brought by those improperly excluded from jury service. Id. at 583 n.5. Neither of these suggestions is likely to be particularly reassuring to defendants. In addition, Justice Powell asserts that review is available by the Supreme Court on direct appeal from a conviction. Id. Again, success in obtaining a reversal through that route is remote for any given defendant, and Justice Powell subsequently questions whether even this amount of federal judicial involvement is appropriate. Id. at 587 n.9.

181 This may explain his unusual willingness to adopt a broad constitutional rule in First Nat'l Bank v. Bellotti. See text accompanying notes 143-44 supra. The rule seems less intrusive if one has confidence in the ability of individuals and other, less wealthy organizations to infiuence political decisionmaking. 
that encourages the assumption of responsibility as well as the assertion of rights. He has done this by focusing on the individual citizen, as others have done, but he emphasizes that the individual finds his greatest happiness in a community and can best exercise power within that context, rather than in opposition to others. For Powell, the state or the municipality should be preserved with as much strength as possible, for local government can be a forum in which people can exercise power over their hives. Nongovernment institutions-the family, even the private corporation-also can play this role and should be encouraged to do so.

There are important corollaries to this theme. First, outsiders, such as judges, should be reluctant to take steps that may threaten institutional balance. When such steps are unavoidable, they should be undertaken with attention to the unique relationships that make up each structure, and generalizations, which obscure understanding, should be avoided. Second, Justice Powell reminds us that institutions, and most particularly the government, are themselves composed of individuals. To woodenly favor the individual over the institution may deprive the individual of the framework in which he would best flourish. 